six and 12 hours after a $1-\mathrm{g}$ dose. ${ }^{19}$ Brumfitt and Pursell ${ }^{2}$ tound that a dose of cephalexin given twice daily was as efficient as a more conventional dose given three or four times a day. Cotrimoxazole has a half life of 10 hours, ${ }^{20}$ and a more constant urinary level would be found throughout treatment.

Cephalexin readily induces spheroplast formation in Gramnegative organisms, which may persist in a hypo-osmotic or iso-osmotic environment. This may be an important cause for a persistent infection (relapse) in a patient treated with cephalexin. We did not look for bacterial variants. Co-trimoxazole is less likely to induce spheroplast formation.

The reinfection rate two weeks after cephalexin was high, representing $40 \%$ of all recurrences. Other workers using cephalexin have also found a relatively high reinfection rate when expressed as a percentage of the overall recurrence rate. ${ }^{1}{ }^{8} 8_{21}$ Comparable figures for reinfection after cotrimoxazole are difficult to obtain from other series. Stamey and Condy ${ }^{22}$ suggested that the reinfection rate after a trimethoprimsulphamethoxazole mixture is low due to the secretion of trimethoprim into the vaginal fluid and eradication of periurethral organisms. Thus co-trimoxazole may have an advantage over cephalexin in reducing both relapses and reinfections.

In the past much emphasis has been placed on the distinction between "relapse" with the same organism (implying treatment failure) and "reinfection" with a different organism or serotype (implying successful treatment). There are several fundamental objections to these claims, which are discussed elsewhere. ${ }^{23}$ In summary, (a) reinfection due to the same organism is impossible to distinguish from a relapse, $(b)$ some organisms are autoagglutinable, and (c) serotyping of 10 colonies obtained from suprapubic aspirates has shown that mixed growths containing more than one serotype occur in at least $2 \%$ of infections. ${ }^{23}$ Such organisms may have different antibiotic sensitivities and be preferentially selected with treatment. These objections make the distinction between relapse and reinfection difficult, and in any study it is conceivable that all the relapses were reinfections with the same organism, or even that the reinfections were relapses with organisms unrecognised in the initial suprapubic aspirate.

We thank Miss R Phillips for technical help. The cephalexin tablets were supplied by Glaxo Laboratories Ltd, and the co-trimoxazole by Burroughs Wellcome \& Co. The identical appearance of the tablets was achieved through co-operation between both manufacturers, for which we are grateful.

\section{References}

${ }_{1}^{1}$ Davies, J A, et al, British Medical fournal, 1971, 3, 215.

2 Brumfitt, W, and Pursell, R, British Medical fournal, 1972, 2, 673.

3 Gower, P E, and Roberts, A P, Clinical Nephrology, 1975, 3, 10.

4 Leigh, D A, and Williams, J D, fournal of Clinical Pathology, 1964, 17, 498.

${ }^{5}$ Mohring, K, Genster, H G, and Madsen, P O, fournal of Urology, 1971, 106, 757.

${ }^{6}$ Montgomery, W G, and Cox, C E, International fournal of Clinical Pharmacology, 1971, 4, 212.

${ }^{7}$ Seneca, H, Uson, A, and Peer, P, fournal of Urology, 1972, 107, 832.

${ }^{8}$ Ries, K M, et al, Antimicrobial Agents and Chemotherapy. 1973, 4, 593.

${ }^{9}$ Gruneberg, R N, and Kolbe, R, British Medical fournal, 1969, 1, 545.

10 Reeves, D S, et al., British Medical fournal, 1969, 1, 541.

11 Wren, B G, Medical fournal of Australia, 1972, 1, 261.

12 Crichton, E P, and McDonnell, C E, Canadian Medical Association fournal, 1972, 107, 292.

13 Gleckman, R A, Fournal of Infectious Diseases, 1973, 128, suppl, p 647.

14 Harding, G K M, and Ronald, A R, Fournal of Infectious Diseases, 1973, 128, suppl, p 641 .

${ }^{15}$ Knudsen, J B, et al., Scandinavian Fournal of Infectious Diseases, 1973, 5, 55.

${ }^{16}$ Cosgrove, M D, and Morrow, J W, fournal of Urology, 1974, 111, 670.

17 Leigh, D A, Faiers, M C, and Brumfitt, W, Postgraduate Medical fournal, 1970, 46, suppl, p 69.

18 Gower, P E, and Dash, C H, British fournal of Pharmacology, 1969, 37, 738.

19 Dash, C H, personal communication.

${ }^{20}$ Schwartz, D E, and Ziegler, W H, Postgraduate Medical fournal, 1969, 45, suppl, p 32.

21 Wise, H A, and Schwartz, H, fournal of Urology, 1971, 105, 440.

${ }^{22}$ Stamey, T A, and Condy, W, fournal of Infectious Diseases, 1975, 131, 261.

${ }^{23}$ Roberts, A P, Gower, P E, and Koutsaimanis, K G, in Proceedings of VI International Congress of Nephrology (Florence), 1975. In press.

\title{
Recurrent haematuria: role of renal biopsy and investigative morbidity
}

\author{
J MICHAEL， N F JONES， D R DAVIES, J R TIGHE
}

British Medical fournal, 1976, 1, 686-688

\section{Summary}

The usefulness of renal biopsy in investigating unexplained haematuria was assessed by a study of 33 adults referred consecutively with this syndrome. Unequivocal abnormalities were seen on light microscopy or immunofluorescence in 31 of the 33 specimens of renal tissue examined. In 18 patients deposits of $\operatorname{IgA}$ were present in the mesangium.

Loin pain occurred in only two of the 18 patients with mesangial IgA deposits, compared with 11 of the 15

St Thomas's Hospital and Medical School, London SE1 7EH J MICHAEL, MB, MRCP, medical registrar

N F JONES, MD, FRCP, consultant physician

D R DAVIES, MB, MRCPATH, senior lecturer in morbid anatomy

J R TIGHE, MD, FRCPATH, professor of histopathology patients without these deposits. Seven of the nine women in this series had had loin pain compared with only six of the 24 men. Thus a woman with loin pain and haematuria was not likely to have mesangial IgA nephropathy but this was found in 14 of the 18 men with unexplained painless haematuria.

Failure to appreciate the role of renal biospy in the investigation of unexplained haematuria may result in unnecessary radiology, considerable morbidity, and even in unjustified nephrectomy.

\section{Introduction}

When haematuria occurs the cause is usually disclosed by urine culture, radiological visualisation of the urinary tracts, and cystoscopy. The results of these investigations, however, are normal in patients with some forms of glomerulonephritis that also may present as recurrent or persistant haematuria. The diagnosis then can be made only by renal biopsy. The value of renal biopsy in this condition has been questioned ${ }^{12}$ and its use 
was not mentioned in a recent leading article on recurrent haematuria. ${ }^{3}$

We report here the value of renal biopsy in 33 consecutive adult patients referred with unexplained haematuria. Failure to appreciate the role of renal biopsy in this condition may lead to excessive and inappropriate investigation, considerable morbidity, and even unwarranted renal surgery. The serious and avoidable consequences that may then ensue are illustrated by some cases in the series we report.

\section{Methods}

The 33 patients were referred over four years. Intravenous urography and cystoscopy had disclosed no abnormality. Needle renal biopsy specimens were obtained in 31 patients and renal tissue obtained at surgery was available for histological examination in the remaining two patients. All specimens were examined by light microscopy and most were also examined by electron microscopy and immunofluorescence using methods previously described. ${ }^{4}$

\section{Results}

Table I gives the main findings in these patients. Definite abnormalities were seen on light microscopy or immunofluorescence in 31 of the 33 renal specimens examined. This compares with an incidence of glomerular abnormalities of $53 \%$ to $100 \%$ in published series of

TABLE I-Histological findings in renal biopsy specimens and clinical data in 33 patients

\begin{tabular}{|c|c|c|c|c|c|c|c|c|}
\hline \multirow{2}{*}{$\begin{array}{l}\text { Case } \\
\text { No }\end{array}$} & \multirow{2}{*}{ Sex } & \multirow{2}{*}{ Age } & \multirow{2}{*}{ Pain } & \multirow{2}{*}{$\begin{array}{c}\text { Mesangial } \\
\text { proliferation } \\
\text { (with or without } \\
\text { increased matrix) }\end{array}$} & \multicolumn{4}{|c|}{ Immunofluorescence } \\
\hline & & & & & IgA & $\operatorname{IgG}$ & IgM & C3 \\
\hline $\begin{array}{r}1 \\
2 \\
3 \\
4 \\
5 \\
6 \\
7 \\
8 \\
9 \\
10 \\
11 \\
12 \\
13 \\
14 \\
15 \\
16 \\
17 \\
18 \\
19 \\
20 \\
21 \\
22 \\
23 \\
24 \\
25 \\
26 \\
27 \\
28 \\
29 \\
30 \\
31 * \\
32 * \\
33^{*}\end{array}$ & $\begin{array}{l}F \\
M \\
M \\
M \\
M \\
M \\
M \\
M \\
M \\
M \\
M \\
M \\
F \\
M \\
M \\
M \\
M \\
M \\
M \\
M \\
F \\
F \\
M \\
M \\
M \\
M \\
M \\
F \\
F \\
M \\
M \\
M \\
F \\
F \\
F\end{array}$ & $\begin{array}{l}22 \\
18 \\
23 \\
24 \\
16 \\
24 \\
22 \\
16 \\
29 \\
16 \\
27 \\
42 \\
16 \\
39 \\
26 \\
39 \\
21 \\
24 \\
23 \\
21 \\
24 \\
17 \\
26 \\
17 \\
48 \\
25 \\
35 \\
20 \\
41 \\
20 \\
20 \\
21 \\
28\end{array}$ & 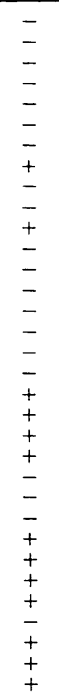 & $\begin{array}{r} \pm \\
++ \\
+ \\
++ \\
\pm \\
+ \\
++ \\
+ \\
+ \\
+ \\
+ \\
+ \\
++ \\
+ \\
+ \\
++ \\
+ \\
\pm \\
+ \\
+ \\
+ \\
+ \\
\pm \\
\pm \\
\pm \\
\pm \\
\pm \\
+ \\
+ \\
\pm \\
\pm \\
\pm \\
+ \\
\pm \\
\pm \\
+ \\
+ \\
+\end{array}$ & $\begin{array}{r}++ \\
++ \\
++ \\
+ \\
+++ \\
+ \\
++ \\
+++ \\
++ \\
++ \\
+++ \\
+++ \\
++ \\
+++ \\
+++ \\
+++ \\
++ \\
+++ \\
= \\
= \\
= \\
= \\
= \\
= \\
= \\
= \\
= \\
-\end{array}$ & $\begin{array}{l} \pm \\
\pm \\
\pm \\
\pm \\
\pm \\
\pm \\
\pm \\
\pm \\
\pm \\
\pm \\
+ \\
\pm \\
\pm \\
\pm \\
\pm \\
\pm \\
\pm \\
\pm \\
\pm \\
\pm \\
\pm \\
\pm \\
\pm \\
\pm \\
\pm \\
\pm \\
\pm\end{array}$ & $\begin{array}{l} \pm \\
\pm \\
\pm \\
\pm \\
\pm \\
+ \\
+ \\
\pm \\
+ \\
++ \\
+ \\
\pm \\
+ \\
++ \\
+ \\
\pm \\
\pm \\
\pm \\
\pm \\
+ \\
\pm \\
\pm \\
\pm \\
\pm \\
\pm \\
+ \\
+ \\
-\end{array}$ & $\begin{array}{l}+ \\
+ \\
+ \\
+ \\
+ \\
+ \\
+ \\
+ \\
+ \\
+ \\
+ \\
++ \\
+ \\
+ \\
+ \\
+ \\
+ \\
+ \\
+ \\
+ \\
+ \\
+ \\
+ \\
+ \\
+ \\
+ \\
+ \\
+\end{array}$ \\
\hline
\end{tabular}

* Medullary calcification on light microscopy. $-=$ Negative. $\pm=$ Doubtful. $+=$ Positive. $++=$ Strongly positive. $+++=$ Very strongly positive. biopsy specimens from adults with haematuria ${ }^{2-8}$ IgA deposits were present in the mesangium in 18 patients and in this group light microscopy showed mesangial abnormalities-namely, hypercellularity or increased matrix - that were unequivocal in 15 cases and doubtful in three. Even in those with doubtful mesangial abnormalities tubular red cell casts were seen, indicating a renal origin for the haematuria. Of these 18 patients with IgA deposition, 12 showed segmental glomerular sclerosis, focal tubular atrophy, and interstitial scarring without evidence of arteriosclerosis. IgA deposits were often accompanied by deposits of complement component $\mathrm{C} 3$, while IgG or IgM deposits were also present in some specimens. Fibrin was found in seven cases. In one further patient with painless haematuria (case 24) the renal biopsy showed slight mesangial proliferation, tubular red cell casts, and deposits of $\mathrm{C} 3$ and $\operatorname{IgM}$ but not of $\operatorname{IgA}$. This patient proved to have a complete lack of circulating and secretory IgA, which may have influenced the pattern of immunoglobulin deposition.

Of the 15 patients without glomerular IgA deposition, only five showed increased mesangial cellularity or increased mesangial matrix, or both, while these changes were equivocal in a further seven patients. Three of those with obvious changes also had segmental glomerular sclerosis. Only five of these 15 patients showed tubular red cell casts in contrast to 12 of the 18 with mesangial IgA deposits. One patient without IgA deposits showed interstitial nephritis and medullary calcification due to previously unrecognised analgesic abuse. A further two patients showed peritubular calcification in the renal papillae and in one of these analgesic abuse was later recognised.

\section{Discussion}

The use of renal biopsy in investigating unexplained haematuria has been questioned or ignored. ${ }^{1-3}$ The high yield of abnormalities provided by renal biopsy in this and other series, ${ }^{25-8}$ however, clearly justifies its use in diagnosis. Examination of the biopsy specimen with immunofluorescence is important, as the recognition of IgA deposits allows classification and bears on the pathogenesis and prognosis. ${ }^{4-11}$ Focal proliferative glomerulonephritis without such IgA deposits may also present as haematuria. In one series of 24 patients with recurrent haematuria 15 showed mesangial deposits of immunoglobulin or complement, but IgA was not present in five of these patients. ${ }^{8}$ In another series haematuria was present in 16 out of 26 patients with focal proliferative glomerulonephritis without IgA deposits. ${ }^{12}$

Loin pain occurred in only two of the 18 patients with mesangial IgA deposits, whereas pain was prominent in 11 of the 15 patients without these deposits. Seven of the nine women in the series complained of pain compared with only six of the 24 men. Thus a woman with loin pain and unexplained haematuria was not likely to have IgA mesangial nephropathy, whereas this condition was found in 14 of the 18 men with painless haematuria. A similarly high proportion of women among patients complaining of loin pain was found by Burden $e t$ al, ${ }^{13}$ who described ischaemic histological lesions and abnormalities of the renal arterial tree in such patients, similar to the findings reported by Little et al. ${ }^{14}$ Arteriosclerotic changes were seen in only four of our 33 specimens. Renal arteriograms were obtained in six of our patients with loin pain and haematuria (five women

TABLE II-Procedures, investigative morbidity, and unnecessary surgery in five young women with recurrent haematuria submitted to avoidable over-investigation

\begin{tabular}{|c|c|c|c|c|c|c|c|c|c|}
\hline \multirow{2}{*}{$\begin{array}{l}\text { Case } \\
\text { No }\end{array}$} & \multicolumn{7}{|c|}{ No of times patient underwent: } & \multirow{2}{*}{ Time in hospital } & \multirow{2}{*}{ Unnecessary surgery } \\
\hline & $\begin{array}{l}\text { Excretion } \\
\text { urography }\end{array}$ & Cystoscopy & $\begin{array}{c}\text { Retrograde } \\
\text { pyelography }\end{array}$ & $\begin{array}{l}\text { Arterio- } \\
\text { graphy }\end{array}$ & Renography & Other radiology & $\begin{array}{r}\text { Renal } \\
\text { biopsy }\end{array}$ & & \\
\hline 20 & 6 & 7 & 4 & 1 & & $\begin{array}{l}\text { Myelography (1), } \\
\text { phlebography (2), } \\
\text { micturating } \\
\text { cystourethrography (1) }\end{array}$ & 2 & $\begin{array}{l}579 \text { days ( } 68 \% \text { of time } \\
\text { from July 1970 to } \\
\text { December 1973) }\end{array}$ & $\begin{array}{l}\text { Denervation of left kidney, } \\
\text { hysterotomy to terminate } \\
\text { pregnancy because of } \\
\text { investigative irradiation }\end{array}$ \\
\hline 21 & 7 & 7 & 4 & 2 & 1 & $\begin{array}{l}\text { Lymphangiography (1), } \\
\text { cholecystography (1), } \\
\text { barium meal }\end{array}$ & 2 & $\begin{array}{l}517 \text { days }(47 \% \text { of time } \\
\text { from } 1968-71)\end{array}$ & \\
\hline 31 & 5 & 1 & 1 & 1 & 3 & $\begin{array}{l}\text { Cholecystography (1), } \\
\text { micturating } \\
\text { cystourethrography (1) }\end{array}$ & 1 & 4 Admissions in 8 months & \\
\hline $\begin{array}{l}32 \\
33\end{array}$ & $\begin{array}{l}3 \\
5\end{array}$ & $\begin{array}{l}3 \\
3\end{array}$ & 2 & 1 & 1 & & & $\begin{array}{l}11 \text { Admissions in } 1969-71 \\
9 \text { Admissions in } 6 \text { years }\end{array}$ & $\begin{array}{l}\text { Right upper lobe nephrectomy } \\
\text { Right nephrectomy }\end{array}$ \\
\hline
\end{tabular}


and one man), but appearances were normal. An automatic film changer was used, however, and Burden et al found this unsatisfactory for recognising fine detail. Hence minor abnormalities may have been missed in our patients.

Failure to realise that recurrent haematuria may result from renal lesions diagnosable only by microscopy led to formidable over-investigation in some of these patients. Table II gives details of five young women who underwent frequent admissions to hospital and repeated radiological investigation. One woman was in hospital for 579 days over three and a half years $(68 \%$ of the total time), and exposure to diagnostic irradiation was enough to necessitate the termination of a mid-trimester pregnancy. One patient had a kidney removed, only for pain to occur for the first time in the other loin within days of the operation. Another woman underwent polar nephrectomy. The kidney substance and vasculature removed in both these patients was histologically normal. A psychogenic and artefactural basis for their complaints was suspected at some time in each of these five women and three had received intensive psychiatric assessment. Possibly the prolonged uncertainty and length of stay in hospital before a firm diagnosis was made were contributing factors. Neither pain nor haematuria has recurred in cases 32 and 33 for 54 and 23 months respectively after firm reassurance and the end of investigation. Even when renal biopsy discloses a lesion for which specific treatment is not available the establishment of a diagnosis prevents unnecessary further investigation, may allow a prognosis to be given, and facilitates management.

\section{References}

1 O'Reilly, P H, Postgraduate Medical fournal, 1974, 50, 746.

2 Burkholder, G V, et al, Fournal of the American Medical Association, 1969, 210, 1729.

${ }^{3}$ British Medical fournal, 1975, 1, 647.

4 Davies, D R, et al, fournal of Clinical Pathology, 1973, 26, 672.

${ }^{5}$ Chen, B T M, et al, Quarterly fournal of Medicine, 1972, 41, 141.

${ }^{6}$ Hendler, E D, Kashgarian, M, and Hayslett, J, Lancet, 1972, 1, 458.

7 Alexander, F, Lannigan, R, and Bull, R, fournal of Clinical Pathology, 1973, 26, 750.

${ }^{8}$ Van de Putte, L B A, de la Riveire, G B, and Van Breda Vriesman, P J C, New England fournal of Medicine, 1974, 290, 1165.

${ }^{9}$ Berger, J, Transplantation Proceedings, 1969, 1, 939.

10 Werra, P de, et al, Schweizerische medizinische Wochenschrift, 1973, 103, 761.

11 Evans, D J, et al, British Medical fournal, 1973, 3, 326.

12 Morel-Maroger, L J, and Verroust, P J, in Recent Advances in Renal Disease, ed N F Jones, chap 2, p 76. London, Churchill Livingstone, 1975.

13 Burden, R P, et al, Quarterly fournal of Medicine, 1975, 44, 433.

${ }_{14}$ Little, P J, Sloper, J S, and De Wardener, H E, Quarterly fournal of Medicine, 1967, 36, 253.

\title{
Rapid glucose absorption in Arabs in Saudi Arabia compared with that in Africans in Zambia
}

\author{
G C COOK
}

British Medical fournal, 1976, 1, 688-689

\section{Summary}

Glucose absorption rates in 14 Arabs in Saudi Arabia were determined by a jejunal perfusion technique and compared with those in 18 Africans in Zambia. None of the subjects had clinical evidence of systemic infection, gastrointestinal disease, malnutrition, or diabetes mellitus. The mean absorption rate was significantly higher in the Arabs. This was associated with a higher incidence of subclinical chronic systemic infection in the Africans. Other factors possibly responsible for the difference, including genetic differences, have, however, not been excluded.

\section{Introduction}

A low jejunal absorption rate of glucose in the presence of high serum $\gamma$-globulin ${ }^{1}$ and IgG $^{2}$ concentrations (probably related to subclinical or inadequately treated infections, especially malaria and schistosomiasis) has been shown in Zambian Africans without clinical evidence of a systemic infection. The glucose absorption rate of Arabs in Saudi Arabia has been determined using the same technique; chronic systemic infections are

\footnotetext{
Department of Medicine, University of Riyadh, Riyadh, Saudi Arabia

G C COOK, MD, FRCP, professor of medicine (present address: Medical Unit, Hospital for Tropical Diseases, London NW1 OPE)
}

uncommon in Riyadh, but schistosomiasis and occasionally malaria occur in Yemeni immigrants.

\section{Subjects and methods}

Fourteen patients (four Bedouin, four urban Saudis living in Riyadh, one Iraqi, and five Yemenis) were studied at the King Abdul Aziz Hospital, Riyadh, after giving their informed consent through an interpreter. They had minor diseases and none had clinical evidence of systemic infection, gastrointestinal disease, malnutrition, or diabetes mellitus. Thirteen were men. Mean age was 25 (16-39) years and mean body weight $54(40-76) \mathrm{kg}$. None was clinically anaemic; in six the mean haemoglobin was $12 \cdot 2(11 \cdot 0-13 \cdot 0) \mathrm{g} / \mathrm{dl}$. Stools from five patients were examined for parasites; one contained a few ova of Schistosoma mansoni. Serum proteins were determined as described, ${ }^{1}$ except that the standard was Seronorm (batch 122) (Nyegaard, Norway). Mean serum albumin concentration was $38(28-44) \mathrm{g} / \mathrm{l}$, and mean $\alpha_{1^{-}}, \alpha_{2}{ }^{-}, \beta-$, and $\gamma$-globulins were $3(2-6) \mathrm{g} / 1,9(6-14) \mathrm{g} / \mathrm{l}, 8$ (6-11) $\mathrm{g} / \mathrm{l}$, and $16(11-24) \mathrm{g} / \mathrm{l}$ respectively. In 10 patients the mean five-hour xylose excretion after a 25 -g oral load ${ }^{1}$ was $47(34-62) \mathrm{mmol}[7 \cdot 0(5 \cdot 13-$ $9.31) \mathrm{g}$; t the mean blood xylose concentration at 90 minutes was $3 \cdot 3(2 \cdot 4-5 \cdot 8) \mathrm{mmol} / \mathrm{l}[50(36-87) \mathrm{mg} / 100 \mathrm{ml}]$.

The glucose absorption rate from a $0 \cdot 2 \mathrm{M}$ glucose solution (which also contained $100 \mathrm{mmol} \mathrm{NaCl}$ and $5 \mathrm{~g}$ polyethylene glycol 4000 per l) was determined for a $30-\mathrm{cm}$ jejunal segment ${ }^{1}$; constant-flow pump, double-lumen perfusion tube (and mercury weight), etc were identical with those used in Zambia, ${ }^{13}$ but glucose was determined by a hexokinase method (Boehringer Mannheim, 15931). The mean distance of the proximal opening of the tube past the duodenojejunal flexure was $9(1-24) \mathrm{cm}$. Reproducibility of the glucose absorption rate ${ }^{4}$ was: mean 1.68 (SD 0.10$) \mathrm{mmol} / \mathrm{min}[0.302$ (SD 0.019) $\mathrm{g} / \mathrm{min}]$; coefficient of variation $=6.3 \%$.

Two additional men with chronic liver disease and portal hypertension were studied. $S$ haematobium and $S$ mansoni were found in their stools, and aspiration liver biopsy in the first showed cirrhosis. Serum albumin concentrations were $34 \mathrm{~g} / \mathrm{l}$ in the first and $28 \mathrm{~g} / \mathrm{l}$ in the second man, and $\gamma$-globulin concentrations were 27 and $25 \mathrm{~g} / 1$ respectively. 